\title{
Crystal and Molecular Structure of 2-Amino-3-Ethyl Carboxamido-4-Metyl-5-Carboxy Ethyl Thiophene
}

\author{
Dhananjay Dey ${ }^{1}$, Venugopal Prakash ${ }^{2}$, Vasu $^{3}$, Janardhanan Saravanan ${ }^{4}$, Deepak Chopra ${ }^{1^{*}}$ \\ ${ }^{1}$ Department of Chemistry, Indian Institute of Science Education and Research, Bhopal, India \\ ${ }^{2}$ Shirdi Sai Engineering College, Bangalore, India \\ ${ }^{3}$ Vivekananda Degree College, Bangalore, India \\ ${ }^{4}$ PES College of Pharmacy, Bangalore, India \\ Email: dchopra@iiserb.ac.in
}

Received October 18, 2012; revised November 15, 2012; accepted November 28, 2012

\begin{abstract}
The crystal and molecular structure of 2-Amino-3-ethyl carboxamido-4-methyl-5-carboxy ethyl thiophene $\left(\mathrm{C}_{11} \mathrm{H}_{16} \mathrm{~N}_{2} \mathrm{O}_{3} \mathrm{~S}\right)$ has been investigated from single crystal X-ray diffraction data. The primary focus is to investigate the molecular geometry of this compound in the solid state along with the associated inter and intra-molecular hydrogen bonding and related weak interactions present in this molecule. This compound crystallizes in the monoclinic space group $P 2{ }_{1} / c$ with cell parameters, $a=8.1344(3) \AA, b=13.7392(4) \AA, c=11.4704(4) \AA, \beta=100.769(2)^{\circ}, \mathrm{V}=1259.36$ (7) $\AA^{3}, \mathrm{D}=1.352$ $\mathrm{g} \cdot \mathrm{cm}^{-3}, \mathrm{Z}=4$. The molecular geometry is stabilized by intra-molecular $\mathrm{N}-\mathrm{H} \ldots \mathrm{O}=\mathrm{C}$ and $\mathrm{C}-\mathrm{H} \ldots \mathrm{O}$ interactions along with intramolecular C-H...N and C-H...O interactions which contribute towards the stability of the crystal packing.
\end{abstract}

Keywords: Crystal; Molecular Conformation; Intermolecular Interactions; Spectroscopy; Diffraction

\section{Introduction}

Thiophene derivatives [1] are of importance in medicinal chemistry and have recently been incorporated into new pharmaceutical and chemical compounds tested as antiinflammatory agents [2]. This class of compounds exhibit pharmacological activity [3-5]. These are also useful in polymer chemistry because of their mechanical strength, ease of fabrication, flexibility in design, stability, resistance to corrosion and low cost [6]. In view of the importance of this class of heterocycles from a biological and pharmaceutical perspective, we report in this manuscript the synthesis of 2-Amino-3-ethyl carboxamido-4-methyl-5-carboxy ethyl thiophene. The compound has been purified and characterized spectroscopically using FT-IR, ${ }^{1} \mathrm{H}$ and ${ }^{13} \mathrm{C}$ NMR techniques. The purity of the phase has been established by powder X-Ray diffraction. Structural characterization of this compound has been achieved via single crystal X-ray diffraction study. Finally, an investigation of the CSD for related compounds containing the thiophene core has also been performed to compare the changes in geometry which accompany the introduction of a 3-ethyl carboxamide and 5-carboxy ester moiety on the thiophene ring.

\section{Experimental}

\subsection{Synthesis of 2-Amino-3-Ethyl Carboxamido- 4-Methyl-5-Carboxy Ethyl Thiophene}

A mixture of ethyl acetoacetate (5.2 g; $0.04 \mathrm{~mol})$, ethyl cyanocetate $(4.52 \mathrm{~g} ; 0.04 \mathrm{~mol})$ and sulphur powder $(1.28$ $\mathrm{g} ; 0.04 \mathrm{~mol})$ in ethanol $(40 \mathrm{ml})$ were added in a round bottomed flask. To this, morpholine $(4.0 \mathrm{ml})$ was added dropwise with stirring [Scheme 1]. The mixture was stirred further for $1 \mathrm{~h}$ at $45^{\circ} \mathrm{C}-50^{\circ} \mathrm{C}$, cooled overnight in ice and the solid product obtained was filtered, washed and recrystallised from ethanol. Pink coloured crystals were obtained and these were used for diffraction purposes. Melting point: $106^{\circ} \mathrm{C}$.<smiles>CCOC(=O)CC(C)=O</smiles>

Scheme 1

*Corresponding author. 


\subsection{Spectroscopic Characterization (FTIR, ${ }^{1} \mathrm{H}$ and ${ }^{13} \mathrm{C}$ NMR) of the Synthesized Compound}

FTIR (in $\mathrm{cm}^{-1}$ : KBr): 3408, 3290, 1681, 1660. ${ }^{1} \mathrm{H}$ NMR $\left(400 \mathrm{MHz}, \mathrm{CDCl}_{3}\right): \delta 6.43(\mathrm{~s}, 2 \mathrm{H}), 4.24(\mathrm{q}, J=7.13 \mathrm{~Hz}$, $2 \mathrm{H}), 4.19$ (q, $J=7.12 \mathrm{~Hz}, 2 \mathrm{H}), 2.63(\mathrm{~s}, 3 \mathrm{H}), 1.30$ (t, $J=$ $7.12 \mathrm{~Hz}, 3 \mathrm{H}), 1.26$ (t, $J=7.12 \mathrm{~Hz}, 3 \mathrm{H}) .{ }^{13} \mathrm{C}$ NMR $(400$ $\left.\mathrm{MHz}, \mathrm{CDCl}_{3}\right): \delta 166.13,166.09,162.88,148.03,108.53$, $108.60,60.41,60.09,16.12,14.40,14.34$.

\subsection{X-Ray Crystallography}

Single-crystal X-ray diffraction data were collected on a three circle Bruker APEX-II diffractometer equipped with a CCD area detector using graphite monochromator and Mo-K $\alpha$ radiation $(\lambda=0.70173 \AA)$ in $\varphi$ and $\omega$ scan modes. The crystal structure of this compound was refined by least-squares method on the basis of all observed reflections using SHELXL-97 [7] present in WinGx [8] (version 1.80). Empirical absorption correction was applied using SADABS [9]. All hydrogen atoms are fixed in geometrical positions. Non-hydrogen atoms are refined with anisotropic displacement parameters. The molecular connectivity was drawn using ORTEP [10] and the crystal packing diagram was drawn using Mercury (CCDC) program [11]. Geometrical calculations were done using PARST [12] and PLATON [13]. The geometrical optimization of the molecule was performed at the B3LYP/6-31G ${ }^{* *}$ level of calculation using TURBOMOLE [14]. The details of the crystal data, data collection and structure refinements are shown in Table $\mathbf{1 .}$

\section{Results and Discussion}

This compound (Figure 1) crystallizes in the monoclinic centro-symmetric space group $P 2_{1} / c$ with four asymmetric units in one unit cell. The crystal structure of the compound $\left(\mathrm{C}_{11} \mathrm{H}_{16} \mathrm{~N}_{2} \mathrm{O}_{3} \mathrm{~S}\right)$ contains one thiophene moiety. One ethyl amide group is connected with $\mathrm{C}(3)$ atom and one ethyl carboxyl group is attached with $\mathrm{C}(1)$ atom. The core structure of the molecule is approximately planar. The geometrical restrictions placed on the intermolecular $\mathrm{H}$-bonds are the sum of the van der Waals radii $+0.4 \AA$ and the directionality is greater than $110^{\circ}$ [15]. Table 2 lists all the intra-molecular and intermolecular interactions. The two intra-molecular $\mathrm{C}(11)-\mathrm{H}(11 \mathrm{~A}) \ldots \mathrm{O}(2)$ and $\mathrm{N}(2)-\mathrm{H}(2 \mathrm{~A}) \ldots \mathrm{O}(1)$ hydrogen bonds stabilize the molecular conformation. Strong $\mathrm{N}(2)-\mathrm{H}(2 \mathrm{~B})$... $\mathrm{O}(2)$ hydrogen bonds forms molecular chains along the crystallographic $b$-axis utilising the screw axis as a symmetry element, whereas weak $\mathrm{C}(10)-\mathrm{H}(10 \mathrm{~A}) \ldots \mathrm{N}(1)$ and $\mathrm{C}(6)-\mathrm{H}(6 \mathrm{~B}) \ldots$ $\mathrm{O}(3)$ intermolecular interactions pack the molecules along the c-axis utilizing the glide plane. These interactions have been recognized as key elements for supramolecular association in the solid state [16-21]. The hydrogen bonding capacity of $\mathrm{O}(1)$ atom is more than the other oxygen atom present in the title molecule. All intermolecular interactions are shown in the packing diagram (Figure 2).

Selected bond distances are shown in Table 3. In Table 4 the experimental torsion angles have been reported.

Table 1. Crystallographic and refinement data of $\mathrm{T} 1$.

\begin{tabular}{|c|c|}
\hline Empirical formula & $\mathrm{C}_{11} \mathrm{H}_{16} \mathrm{~N}_{2} \mathrm{O}_{3} \mathrm{~S}$ \\
\hline Formula weight & $256.32 \mathrm{~g} / \mathrm{mole}$ \\
\hline Crystal colour & Pink \\
\hline Temperature & $298 \mathrm{~K}$ \\
\hline Wavelength & $0.71073 \AA$ \\
\hline Crystal system & Monoclinic \\
\hline Space group & $P 2_{1} / c$ \\
\hline Unit cell dimensions & $\begin{array}{c}a=8.1344(3) \AA, b=13.7392(4) \AA \\
c=11.4704(4) \AA, \beta=100.769(2)^{\circ}\end{array}$ \\
\hline Volume & $1259.36(7) \AA^{3}$ \\
\hline Z, Calculated density & $4,1.352 \mathrm{Mg} \cdot \mathrm{m}^{-3}$ \\
\hline Absorption coefficient & $0.256 \mathrm{~mm}^{-1}$ \\
\hline$F(000)$ & 544 \\
\hline Crystal size & $0.2,0.1,0.1 \mathrm{~mm}$ \\
\hline Theta range for data collection & $2.34^{\circ}$ to $27.43^{\circ}$ \\
\hline Limiting indices & $-10 \leq \mathrm{h} \leq 10,-16 \leq \mathrm{k} \leq 17,-14 \leq \mathrm{k} \leq 14$ \\
\hline $\begin{array}{c}\text { Reflections } \\
\text { collected/unique }\end{array}$ & $10475 / 2853[R($ int $)=0.0275]$ \\
\hline Completeness to theta $=27.43$ & $0.99 \%$ \\
\hline Max. and min. transmission & $0.9749,0.9506$ \\
\hline Refinement method & Full-matrix least-squares on $F^{2}$ \\
\hline Data/restraints/parameters & $2368 / 0 / 158$ \\
\hline Goodness-of-fit on $F^{2}$ & 1.076 \\
\hline $\begin{array}{l}\text { Final } R \text { indices } \\
{[I>2 \text { sigma(I)] }}\end{array}$ & $R_{1}=0.0475, \mathrm{w} R_{2}=0.1449$ \\
\hline $\mathrm{R}$ indices (all data) & $R_{1}=0.0655, \mathrm{w} R_{2}=0.1554$ \\
\hline Largest diff. peak and hole & $0.563 \mathrm{e} \cdot \AA^{-3}$, and $-0.637 \mathrm{e} \cdot \AA^{-3}$ \\
\hline
\end{tabular}

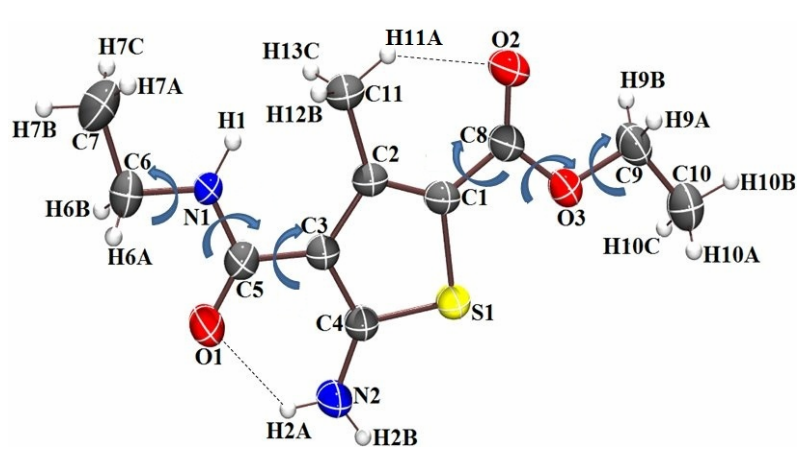

Figure 1. ORTEP of the synthesized molecule drawn with $50 \%$ ellipsoidal probability. The dotted lines indicates intra-molecular $\mathrm{N}(2)-\mathrm{H}(2 \mathrm{~A}) . . . \mathrm{O}(1)$ and $\mathrm{C}(11)-\mathrm{H}(11 \mathrm{~A}) . . . \mathrm{O}(2)$ hydrogen bonds. Bending arrows are showing the torsion angles in the asymmetric unit. 
Table 2. Intra- and Intermolecular Interactions in the compound.

\begin{tabular}{|c|c|c|c|c|c|}
\hline & $\begin{array}{l}\text { D-H } \\
(\AA)\end{array}$ & $\begin{array}{c}\text { D...A } \\
(\AA)\end{array}$ & $\begin{array}{c}\text { H...A } \\
(\AA)\end{array}$ & $\begin{array}{c}\text { D-H...A } \\
\left(^{\circ}\right)\end{array}$ & $\begin{array}{c}\text { Symmetry } \\
\text { Code }\end{array}$ \\
\hline (11)- & 1.08 & $3.027(3)$ & 2.21 & 131 & \\
\hline $\mathrm{N}(2)$ & 1.03 & 2.685 & 1.99 & 122 & \\
\hline $\mathrm{C}(10)-\mathrm{H}$ & 1.08 & $3.593(3)$ & 2.75 & 134 & $\begin{array}{l}x+ \\
1 / 2,\end{array}$ \\
\hline $\mathrm{Cr}$ & 1.08 & 3.7 & 2.79 & 150 & $\begin{array}{l}-y+ \\
-1 / 2\end{array}$ \\
\hline$C(10)$ & 1.08 & 3.762 & 2.71 & 162 & $\mathrm{x}+1, \mathrm{y}, \mathrm{z}+1$ \\
\hline $\mathrm{N}(2)-\mathrm{H}(2 \mathrm{~B}$ & 1.03 & $2.931(2)$ & 1.95 & 158 & $\begin{array}{c}-\mathrm{x}, \mathrm{y}+1 / 2 \\
-\mathrm{z}+1 / 2 \\
\end{array}$ \\
\hline
\end{tabular}

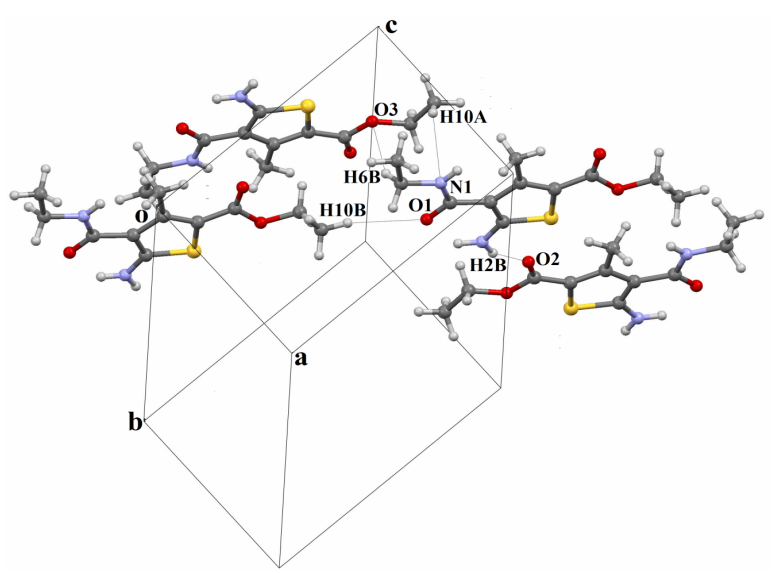

Figure 2. Packing diagram and intermolecular $\mathrm{H}$ bonds.

Table 3. Selected bond distances.

\begin{tabular}{cc}
\hline Bond & Distance $(\AA)$ \\
\hline $\mathrm{C}(3)-\mathrm{C}(5)$ & $1.46(3)$ \\
$\mathrm{C}(5)=\mathrm{O}(1)$ & $1.21(3)$ \\
$\mathrm{C}(5)-\mathrm{N}(1)$ & $1.34(3)$ \\
$\mathrm{N}(1)-\mathrm{C}(6)$ & $1.45(3)$ \\
$\mathrm{C}(1)-\mathrm{C}(8)$ & $1.45(3)$ \\
$\mathrm{C}(8)=\mathrm{O}(2)$ & $1.21(3)$ \\
$\mathrm{C}(8)-\mathrm{O}(3)$ & $1.34(3)$ \\
$\mathrm{O}(3)-\mathrm{C}(9)$ & $1.44(2)$ \\
\hline
\end{tabular}

Table 4. Selected torsion angles in degree $\left(^{\circ}\right)$.

\begin{tabular}{cc}
\hline Torsion & Angles $\left(^{\circ}\right)$ \\
\hline $\mathrm{C}(5)-\mathrm{N}(1)-\mathrm{C}(6)-\mathrm{C}(7)$ & $178.4(2), 159.6(1)^{\mathrm{a}}$ \\
$\mathrm{C}(6)-\mathrm{N}(1)-\mathrm{C}(5)-\mathrm{C}(3)$ & $179.0(2), 176.1(1)$ \\
$\mathrm{C}(4)-\mathrm{C}(3)-\mathrm{C}(5)-\mathrm{N}(1)$ & $179.8(2), 171.6(1)$ \\
$\mathrm{C}(2)-\mathrm{C}(1)-\mathrm{C}(8)-\mathrm{O}(3)$, & $177.3(2), 179.4(1)$ \\
$\mathrm{C}(9)-\mathrm{O}(3)-\mathrm{C}(8)-\mathrm{C}(1)$ & $180.0(2), 179.8(1)$ \\
$\mathrm{C}(8)-\mathrm{O}(3)-\mathrm{C}(9)-\mathrm{C}(10)$ & $176.3(2), 179.4(1)$ \\
\hline
\end{tabular}

( ${ }^{\mathrm{a}}$ : Italicised values obtained from theoretical B3LYP/6-31G ${ }^{* *}$ calculation).

It is of interest to note that the torsion $\mathrm{C}(2)-\mathrm{C}(1)-\mathrm{C}(8)$ $\mathrm{O}(3)$ and $\mathrm{C}(4)-\mathrm{C}(3)-\mathrm{C}(5)-\mathrm{N}(1)$ are $177.2(2)^{\circ}$ and $179.8(2)^{\circ}$ indicating planarity with the thiophene ring assisted by delocalisation between the carboxy and carboxamide groups at $\mathrm{C}(1)$ and $\mathrm{C}(3)$ respectively. The theoretical B3LYP/6-31G ${ }^{* *}$ calculations, after geometrical optimization of the molecule, reveal torsion angles and these have been compared with the experimental values. In most of the cases the experimental torsion angles are compareable with the theoretical values. But for $\mathrm{C}(5)-\mathrm{N}(1)$ $\mathrm{C}(6)-\mathrm{C}(7)$, the difference in torsion angle is approximately $18^{\circ}-19^{\circ}$, signifying the importance of crystal forces in the packing of molecules. In Table 5 the search information, retrieved from the Cambridge Structural Database [22] on the presence of specific functional groups on the thiophene moiety has been presented. Search numbers 1 and 2 for the presence of carboxy ester and carboxamide moiety only on the thiophene ring revealed 1 hit only [Structures (A) and (B), Table 5]. Search numbers 3 and 4 revealed no hits. It is of interest to compare the torsion angles $\mathrm{C}(2)-\mathrm{C}(1)-\mathrm{C}(8)-\mathrm{O}(3)$ and $\mathrm{C}(4)-\mathrm{C}(3)-\mathrm{C}(5)-\mathrm{N}(1)$ in the present compounds with those in (A) [23] and (B) [24] respectively. These values are $179.9^{\circ}$ and $170.2^{\circ}$ respectively.

The phase purity of the compound has been verified by powder X-ray diffraction. It is of interest to note that the experimental and simulated powder patterns (generated from crystallographic coordinates) have a one-to-one correspondence, thereby confirming the single phase behaviour of the compound (Figure 3).

\section{Conclusion}

The title compound is of biological importance and the synthesis of related thiophene compounds is of significance. This is reflected from the CSD wherein related compounds having different functionalities are scarce and hence new compounds can be synthesised, characterized and investigated for their crystal structures. It is of interest to investigate polymorphism in such solids and screen such compounds for their medicinal property. These are expected to have concomitant commercial ramifications in the pharmaceutical industry.

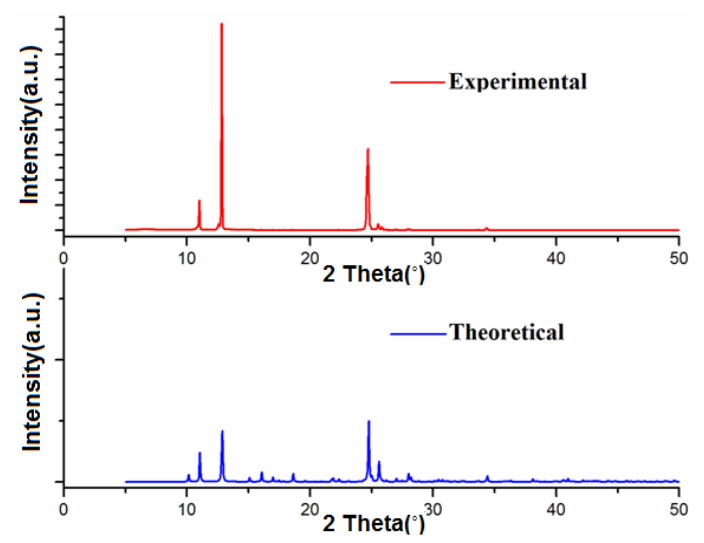

Figure 3. Experimental and theoretical powder pattern for the title compound. 
Table 5. CSD [17] search information.

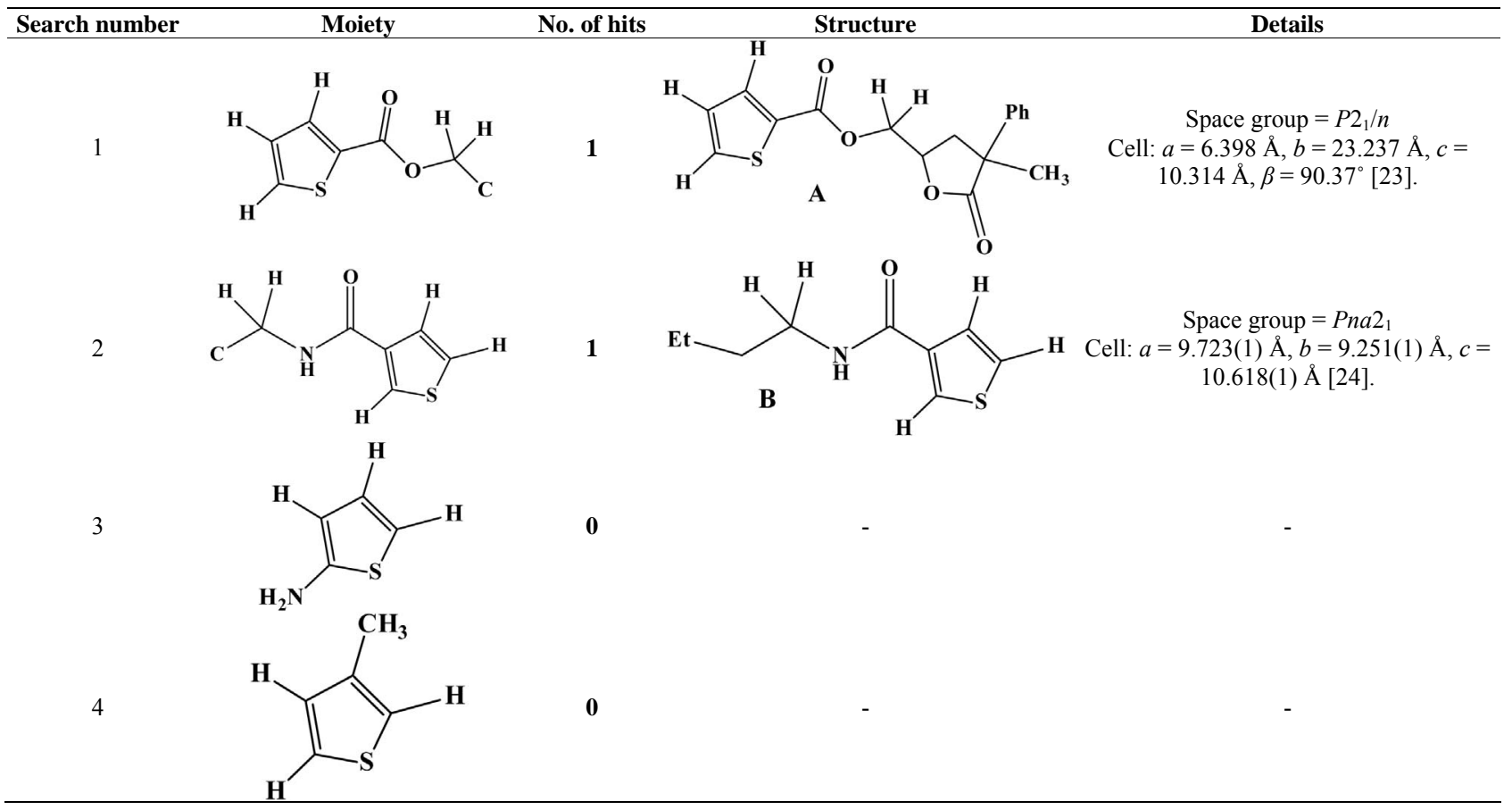

\section{Acknowledgements}

DC thanks IISER Bhopal for research facilities and DSTFast track scheme for research funding.

\section{REFERENCES}

[1] R. Mishra, K. K. Jha, S. Kumar and I. Tomer, "Synthesis, Properties and Biological Activity of Thiophene: A Review," Der Pharma Chemica, Vol. 3, No. 4, 2011, p. 38.

[2] G. Darshan, D. Chopra and J. Saravanan, "N-(X-Methylphenyl)-2- $\{(Z)-[(2,3,4$-trimethoxyphenyl)methylidene $]$ am ino -4,5,6,7-tetrahydro-1-benzothiophene-3-carboxamide, where X $=2$ and 3," Acta Crystallographica, Vol. C66, No. 12, 2010, p. 571.

[3] Vasu, K. A. Nirmala, D. Chopra, S. Mohan and J. Saravanan, Acta Crystallographica, Vol. C60, No. 11, 2004, p. 786.

[4] Vasu, K. A. Nirmala, D. Chopra, S. Mohan and J. Saravanan, Acta Crystallographica, Vol. C60, No. 9, 2004, p. 636.

[5] Vasu, K. A. Nirmala, D. Chopra, S. Mohan and J. Saravanan, Acta Crystallographica, Vol. E60, No. 2, 2004, p. 236.

[6] H. S. O. Chan and S. C. Ng, "Synthesis, Characterization and Applications of Thiophene-Based Functional Polymers," Progress in Polymer Science, Vol. 23, No. 7, 1998, pp. 1167-1231. doi:10.1016/S0079-6700(97)00032-4

[7] G. M. Sheldrick, "SHELXL97, Program for Crystal Structure Refinement," University of Gottingen, 1997.

[8] L. J. Farrugia, "WinGX Suite for Small-Molecule Single-Crystal Crystallography," Journal of Applied Crys- tallography, Vol. 32, No. 4, 1999, pp. 837-838. doi:10.1107/S0021889899006020

[9] G. M. Sheldrick, "A Short History of SHELX," Acta Crystallographica, Vol. A64, No.1, 2008, p. 112.

[10] L. J. Farrugia, "ORTEP-3 for Windows-A Version of ORTEP-III with a Graphical User Interface (GUI)," Journal of Applied Crystallography, Vol. 30, No. 5, 1997, p. 565. doi:10.1107/S0021889897003117

[11] C. F. Macrae, I. J. Bruno, J. A. Chisholm, P. R. Edgington, P. McCabe, E. Pidcock, L. Rodriguez-Monge, R. Taylor, J. Streek and P. A. Wood, "Mercury CSD 2.0New Features for the Visualization and Investigation of Crystal Structures," Journal of Applied Crystallography, Vol. 41, No. 2, 2008, pp. 466-470. doi:10.1107/S0021889807067908

[12] M. Nardelli, "PARST95-An Update to PARST: A System of Fortran Routines for Calculating Molecular Structure Parameters from the Results of Crystal Structure Analyses," Journal of Applied Crystallography, Vol. 28, No. 5, 1995, p. 569. doi:10.1107/S0021889895007138

[13] A. L. Spek, "PLATON-a Multipurpose Crystallographic Tool," Utrecht University, 2002.

[14] I. Dance, "Distance Criteria for Crystal Packing Analysis of Supramolecular Motifs," New Journal of Chemistry, Vol. 27, No. 1, 2003, pp. 22-27. doi: $10.1039 / \mathrm{b} 206867 \mathrm{~b}$

[15] Turbomole V6.3 2011, “A Development of University of Karlsruhe and Forschungszentrum Karlsruhe GmbH, 1989-2007, Turbomole GmbH,” 2007. http://www.turbomole.com.

[16] G. R. Desiraju and T. Steiner, "The Weak Hydrogen Bond in Structural Chemistry and Biology," Oxford University Press, Oxford, 1999. 
[17] G. R. Desiraju, "C-H...O and Other Weak Hydrogen Bonds. From Crystal Engineering to Virtual Screening," Chemical Communication, 2005, pp. 2995-3001. doi:10.1039/b504372g

[18] G. R. Desiraju, "Hydrogen Bridges in Crystal Engineering: Interactions without Borders," Accounts of Chemical Research, Vol. 35, No. 7, 2002, pp. 565-573. doi:10.1021/ar010054t

[19] S. S. Kuduva, D. C. Craig, A. Nangia and G. R. Desiraju, "Cubanecarboxylic Acids. Crystal Engineering Considerations and the Role of $\mathrm{C}-\mathrm{H}$...O Hydrogen Bonds in Determining O-H...O Networks," Journal of the American Chemial Society, Vol. 121, No. 9, 1999, p. 1936. doi:10.1021/ja981967u

[20] T. Steiner, Chemical Communication, No. 8, 1997, pp. 727-734. doi:10.1039/a603049a
[21] G. R. Desiraju, "The $\mathrm{C}-\mathrm{H} \cdots \mathrm{O}$ Hydrogen Bond: Structural Implications and Supramolecular Design," Accounts of Chemical Research, Vol. 29, No. 9, 1996, pp. 441-449. doi:10.1021/ar950135n

[22] CSD Version 5.33, "The Following Constraints Were Applied: No Refcode Restrictions Applied, 3D Coordinates Determined, R Factor $\leq 0.1$, No Errors, Not Polymeric, No Ions, Only Organics," 2011.

[23] I. F. Cottrell, A. R. Cowley, L. J. Croft, L. Hymns, M. G. Moloney, E. J. Nettleton, H. K. Smithies and A. L. Thompson, "Acyloxylactonisations Mediated by Lead Tetracarboxylates," Tetrahedron, Vol. 65, No. 12, 2009, pp. 2537-2550. doi:10.1016/j.tet.2009.01.042

[24] R. W. Gable, M. J. Laws, C. H. Schiesser, Acta Crystallographica, Vol. C53, No. 5, 1997, p. 641. 